\title{
Factors Determining the Credit Accessibility by the Small-Scale Entrepreneurs: A Case of Handloom Weaving in Bangladesh
}

\author{
Mst Tania Parvin ${ }^{1,2}$, Kanij Fatema ${ }^{3} \&$ Sadika Haque $^{4}$ \\ ${ }^{1}$ Department of Agribusiness, Bangabandhu Skeikh Mujibur Rahman Agricultural University (BSMRAU), \\ Bangladesh \\ ${ }^{2}$ Institute of Agricultural Sciences in the Tropics (Hans-Ruthenberg Institute 490C), University of Hohenheim, \\ Germany \\ ${ }^{3}$ Department of Agricultural Economics and Policy, Sylhet Agricultural University, Bangladesh \\ ${ }^{4}$ Department of Agricultural Economics, Bangladesh Agricultural University, Bangladesh \\ Correspondence: Mst Tania Parvin, Assistant Professor, Department of Agribusiness, Bangabandhu Skeikh \\ Mujibur Rahman Agricultural University (BSMRAU), Gajipur-1706, Bangladesh. E-mail: \\ taniaparvin2011@yahoo.com, tania.bsmru@gmail.com
}

Received: May 18, 2020

Accepted: June 22, 2020

Online Published: July 10, 2020

doi:10.5539/ijbm.v15n8p93

URL: https://doi.org/10.5539/ijbm.v15n8p93

\begin{abstract}
This study examines the determinants of access to credit by the handloom weavers in Bangladesh. Using the multistage sampling technique, the primary data for the analysis were collected from 311 randomly selected handloom weavers from Sirajganj district of Bangladesh during July to December 2015. The data are analyzed by using the Logit model. The model identifies several individual, household, community, and institution-specific factors as the significant determinants of credit access. Among them, family size, farm size, work experience, saving and the flexibility in the terms and conditions of loan use increase the probability of credit access by the handloom weavers whereas the risk aversion attitude and the distance between the Microfinance Institutions (MFIs) from the commune reduce such possibility. Therefore, this study suggests that respondents should utilize the joint effort of the available family members in this labor-intensive business while undertaking rational decisions enhanced through the skills and capabilities acquired over the years. They should maintain a sufficient amount of saving to prove them eligible in repaying their credit. From the institutional perspective, it is suggested that the MFIs should provide adequate financial and non-financial services to its clientele as per their needs. Borrowers' easy accessibility to the institutions should also be ensured. In doing so, they should open up more branches in the villages so that the door to door services are available to the borrowers. It is expected that these recommendations will help in improving the credit access by the handloom weavers in Bangladesh.
\end{abstract}

Keywords: Bangladesh, credit accessibility, small-scale entrepreneurs, handloom weaving, Logit model

\section{Introduction}

\subsection{Background of the Study}

The rural development agenda of the governments in most of the developing countries are largely dependent on the agricultural production. However, in countries like Bangladesh where the land size is very small per head and is continuously deteriorating due to the increased population pressure, the non-agricultural sector can play a prominent role in small-scale entrepreneurship development as well as increasing the income than the agricultural sector. The agricultural sector is also subjected to seasonal risk and uncertainties, thereby, may not contribute to the sustainable livelihood development of the poor population (Reardon, Crawford, \& Kelly, 1994; Pitt, 2000; McNamara \& Weiss, 2005).

Among the various small-scale entrepreneurship development choices, handloom weaving ${ }^{1}$ can be the priority option with regard to being the largest and most crucial non-agricultural employment provider next to agricultural sector in Bangladesh. It is a traditional and labor-intensive cottage industry which potentially employs more than 1.5 million populations in this highly populated country (Parvin \& Haque, 2017). Each year, the handloom sector earns more than 10 billion Bangladeshi Taka (BDT) from the export of handloom products 
(Rahman, 2013, p. 11; Liton, Islam, and Saha, 2016, p. 70). As per the latest 'Handloom Census' conducted in 2003, more than $28 \%$ demand for one of the most important non-consumable basic needs (i.e., cloth) is met by the production from this handloom industry (Bangladesh Bureau of Statistics [BBS], 2003, p. 13). Because of all these potentials, this sector's significance is ranked as second after the agricultural sector for the development of rural economy (Islam \& Hossain, 2012; Rahman, 2013; Rahman, Mukul, \& Anny, 2014; Liton et al., 2016).

\subsection{Problem Statement}

Despite various potentials, the handloom weaving sector is performing beyond the expectation due to several barriers. For example, the dominance of cost-intensive power loom has increased the competition and hampered the market for handloom products, thereby, has slowed the pace of handloom growth. On the other hand, the increase in the gas price has increased the cost of raw materials. The quality material is also not available at the local level. The technology adoption for modernizing the product design is also subjected to available capital which is beyond the reach of the handloom weavers. Because of all these reasons, many of the handloom weavers are leaving their traditional occupation from the past two decades which is expected to have unemployment effect on the rural economy of Bangladesh. Many others are migrating to the neighboring country India (Banarjee, Muzib, \& Sharmin, 2014). All these circumstances call for credit or capital to help these weavers sustaining their livelihood in the rural setup.

The problem of shortage of capital is not new. It was identified as the primary cause of shutoff of the handlooms in Bangladesh as per the Handloom Census of 1990 and 2003. In 2003, out of total 505556 handlooms, more than $38 \%$ was unproductive over the year due to the capital constraint. In 1990, this figure was nearly $32 \%$ (BBS, 2003 , p. 18, 35). Even though no latest estimate is found on this statistic, yet, one can speculate that this rate would be nearly $45 \%$ in 2018 if the trend is assumed to be constant. Such speculation implies that day by day the handloom sector is going to extinction due to the shortage of fund and thus is prohibiting the entrepreneurship development in the rural economy.

Handloom weavers are regarded as the small-scale entrepreneurs in Bangladesh. However, several authors (e.g., Gelos \& Werner, 2002; Kohansal, Ghorbani, \& Mansoori, 2008; Hertz, 2009; Love \& Sánchez, 2009) have noted that the growth potential of many small and medium-scale enterprises in developing countries is constrained by the lack of working capital in purchasing adequate raw materials or adoption of technology. This situation hampers the operational efficiency and shrinks the business scale as well as the economic growth of the country.

Fortunately, the microcredit programs have paved the way of survival for many handloom weavers. Islam and Hossain (2012) noted that many of the handloom weavers are undertaking credit from different formal and informal sources on a large scale in the present context. It is because, microcredit (broadly known as microfinance) introduced by Mohammad Yunus during the 1970s has been proved as an useful instrument of poverty reduction, entrepreneurship development, employment generation, vulnerability reduction and much more since its inception from Bangladesh. Therefore, it is being used as an important development policy of the governments in many Asian, African and Latin American countries (Sharma \& Zeller, 1997; Siwale \& Ritchie, 2011; Rahman, Luo, Ahmed, \& Xioalin, 2012). Though there are some formal terms and conditions of access to credit but which factors truly (sometimes informally) determine the credit access of the small-scale entrepreneurs like handloom weavers is missing from the available microfinance studies. Although a substantial number of studies assessed the credit access of the agricultural households (e.g., Aliero \& Ibrahim, 2011; Dzadze, Osei, Aidoo, \& Nurah, 2012; Chauke, Motlhatlhana, Pfumayaramba, \& Anim, 2013; Karanja, Mwangi, \& Nyakarimi, 2014; Anang, Sipiläinen, Bäckman, \& Kola, 2015 and many others), such study is limited to the non-agricultural households which indicates a research gap.

\subsection{Objective of the Study}

Based on the above background, this study aims to fill the knowledge gap by identifying the factors that may help to increase credit access by small-scale entrepreneurs such as handloom weavers in Bangladesh so that these households can sustain their livelihood in the rural setup. From the policy perspective, it is expected that this study will contribute to the appropriate policy formulation for the small-scale entrepreneurs by facilitating the eligible client selection who need the credit most than others.

The rest of the paper is organized into three different sections. Section two summarizes the methodology of the study followed by the results and discussion in section three. Finally, the study concludes and draws recommendations in section four.

\section{Materials and Method}

For conducting the highlighted study, the primary data was collected from 311 randomly selected handloom 
weavers from four sub-district name Shahjadpur, Ullapara, Raiganj and Belkuchi under Sirajganj district of Bangladesh during July to December 2015. According to the 'Handloom Census 2003', this district is ranked $1^{\text {st }}$ regarding the number of the handloom establishment (BBS, 2003, p. 28). It holds nearly 14870 handloom weaving units and accounts for $36 \%$ of total 50 million meter handloom cloth production within the country (BBS, 2003, p. $29,81)$. The multistage sampling technique was employed for achieving the purpose. The sample size varied in different study areas due to the non-availability of the households bearing the similar socioeconomic background. The data were recorded on the borrowers' socioeconomic status, resource endowment, income, expenditure, savings, and most importantly the access to different formal and informal credit sources. Besides primary data, secondary data were also collected from the Bangladesh Bureau of Statistics (BBS), Bangladesh Handloom Board (BHB), different published and unpublished articles, reports, books, and other sources. Finally, the Logit model ${ }^{2}$ was applied to analyze the data in a statistical software package called 'STATA 12' which provided the result using the maximum likelihood (ML) estimation approach in identifying the factors that determine the respondents' access to the financial services. The specification of the Logit model is adopted from Gujarati and Porter (2008) as follows:

$$
L_{i}=\left(\frac{P_{i}}{1-P_{i}}\right)=Z_{i}=\beta_{1}+\beta_{2} X_{i}
$$

Where $\mathrm{L}$ is called the Logit model and is usually used to estimate the equations having a binary outcome, $P_{i} / 1-P_{i}$ indicates the odds ratio of households having their access to credit $\left(P_{i}=1\right)$ to those who are excluded from such opportunities $\left(P_{i}=0\right), \beta^{\prime} s$ are the parameters to be estimated and $X_{i}$ 's are the ith the explanatory variables.

\section{Results and Discussion}

\subsection{Descriptive Statistics}

The descriptive statistics of the variables used in the Logit model are presented in Table 1. The table shows that out of total 311 sample, only $64 \%$ were having their access to credit during 2015 . Therefore, they could be regarded as the credit accessed households, and the rest could be called as the non-accessed group. The mean age of respondents was nearly 44 years and they were literate with a very minimal level of education (i.e., below primary school). The respondents were having an average family size of more than five.

Among the total sample, the majority of the respondents (64\%) were having the land size of less than 0.50 acre who are regarded as poor and are incapable of bearing the collateral under most of the microcredit programs in Bangladesh. Approximately $68 \%$ of the respondents were involved in multiple occupations than handloom weaving. They were substantially experienced (nearly 22 years) in their occupations. On an average, the market value of their assets was approximately Bangladeshi Taka (BDT) ${ }^{3} 191278$, and they owned more than five operational handloom machines ${ }^{4}$ during the year. They were able to save nearly BDT 94391 after meeting their food and non-food expenditures.

The reason for undertaking the credit by $51 \%$ of the respondents was to avoid the risk of doing the business. To obtain the credit, they had to travel nearly $6 \mathrm{~km}$ from their commune. About $66 \%$ of them claimed that the terms and conditions of loan use imposed by the lenders were not flexible for them. 
Table 1. Descriptive statistics of the variables used in the Logit model estimation $(\mathrm{N}=311)$

\begin{tabular}{lll}
\hline Variables & Proportion/Mean & Standard deviation \\
\hline Dependent variable & & \\
Credit access $(1=$ yes, 0$)$ & $64 \%, 36 \%$ & - \\
Independent variable & & \\
Age (years) & 43.93 & 0.72 \\
Education(years) & 4.45 & 0.21 \\
Family size & 5.36 & 0.12 \\
Farm size $(1=$ less than 0.50 acre, 0$)$ & $27 \%, 73 \%$ & - \\
Occupational status $(1=$ multiple, 0$)$ & $68 \%, 32 \%$ & - \\
Working experience (years) & 21.99 & 0.75 \\
Household assets (BDT) & 191278.30 & 10218.47 \\
Operational loom (no.) & 5.11 & 0.19 \\
Savings (BDT) & 94391 & 10464 \\
Attitude towards risk aversion $(1=$ yes, 0$)$ & $51 \%, 49 \%$ & - \\
Terms and conditions $(1=$ flexible, 0$)$ & $34 \%, 66 \%$ & - \\
Distance of MFIs from the villages & 5.76 & 4.05 \\
\hline
\end{tabular}

Note. The descriptive statistics of the continuous variables are presented in mean value whereas the dummy variables are presented in percentage to the total population.

Source. Field survey, 2015.

\subsection{Results of the Logit Model Estimation}

The final estimation results are presented in Table 2. It identifies seven variables as the significant determinants of credit access by the handloom weavers in Bangladesh. All other variables are identified as insignificant which implies the irrelevance of these variables in this analysis.

The positive coefficient sign of the family size implies that the increase in this number is comparatively advantageous with regard to reducing the cost for hired labor for the studied labor-intensive business. Similarly, these members may work jointly either in the same business or in different off-farm activities to earn extra money which will help them in repaying the loan amount. Therefore, they will not fear for the debt and will be interested in participating in the credit program. Such assumption from the supply-side will also pave their entry to the credit program. This finding contradicts with Motsoari, Cloete, \& van Schalkwyk (2015) and Anang et al., (2015) who estimated opposite significant and insignificant relationship between these two variables.

As expected, the proximity of the households having the farm size of less than 0.50 acre is more likely to get the access to the credit programs. As discussed in section 3.1, it can be reinforced here that the households under this category are regarded as poor who are usually deprived of the banking facilities due to not having the collateral against their lending. As the microcredit programs aim to bring this client group under the banking culture, their access is facilitated due to the small land size. This finding is in accordance with Motsoari et al. (2015) who also estimated a positive sign for this variable whereas it contradicts with the Anang et al. (2015) who estimated an insignificant negative sign.

A very straightforward finding regarding the work experience can be interpreted as that an experienced business entrepreneur is better able to run and maintain the business profitability and is likely to repay on time. Therefore, the credit institutions are interested in lending them the money. Hence, this variable determines the credit access. This finding is disproportional to Anang et al. (2015) who failed to identify this variable as the significant indicator of credit access.

The positive correlation between saving and credit access is also explicit. A household with higher saving is expected to repay their loan on-time. Therefore, that person is less likely to default and more likely to get the credit access. This finding deviates from Motsoari et al. (2015) who argued that saving decreases and substitutes the demand for credit.

The willingness of the household to participate in the credit program is thought to be proportional to their risk aversion attitude. However, the estimated negative result proves that the story may not be always true. The plausible explanation of this finding would be that households do not only participate in the credit program just because of avoiding the business risk. There might have some other factors which are more important to them for their participation decision. The motivation for entrepreneurship development or the motivation to be economy 
solvent through expanding the business with credit could be two of such examples.

The result of the qualitative variable flexibility in the terms and conditions of loan use is positive and significant. In line with Diagne and Zeller (2001), this finding can be interpreted as that not only the financial incentives, but also the non-financial services such as relaxing the grace period of initial loan installment, providing advice on productive utilization of loan, training on capacity building and the likes encourage the borrowers demanding the credit. Therefore, as much flexibility the MFIs will ensure to the clients as many members will participate in the program.

In line with Luan (2015), it can be said that the respondents are less likely to participate in the credit program due to the addition of distance they travel from their villages to obtain the credit.

Table 2 also presents the marginal effect of the explanatory variables at their mean values. It is calculated to find out the actual magnitude or change in the probabilities of a particular happening. For binary variables, it represents the change in the probability due to a discrete change between 0 to 1 considering all other variables as constant (Torres-Reyna, 2014; Williams, 2016). The marginal effect of the dummy variable farm size is normally interpreted as a comparison to the base group. For example, the result of the variable farm size can be interpreted as that can be interpreted as that if some of the households having more than 0.5 acre $(X=0)$ enters to the first category $(X=1)$, their probability of getting the credit access will be increased by 0.36 unit. It should be noted here that the marginal effect is interpreted in terms of both sign and magnitude. For the continuous variable, it expresses the rate of instantaneous change in the probability due to a unit change in the independent variable. For example, the marginal effect of the variable family size can be interpreted as that an addition of a family member will increase the chance of credit access by $35 \%$. Likewise all other variables of dummy and continuous nature can be interpreted. It is further noted that the marginal effect identifies the same variables as significantly determining the credit access with the same sign. Only their extent differs from the coefficient values.

Table 2. Results of Logit model estimation

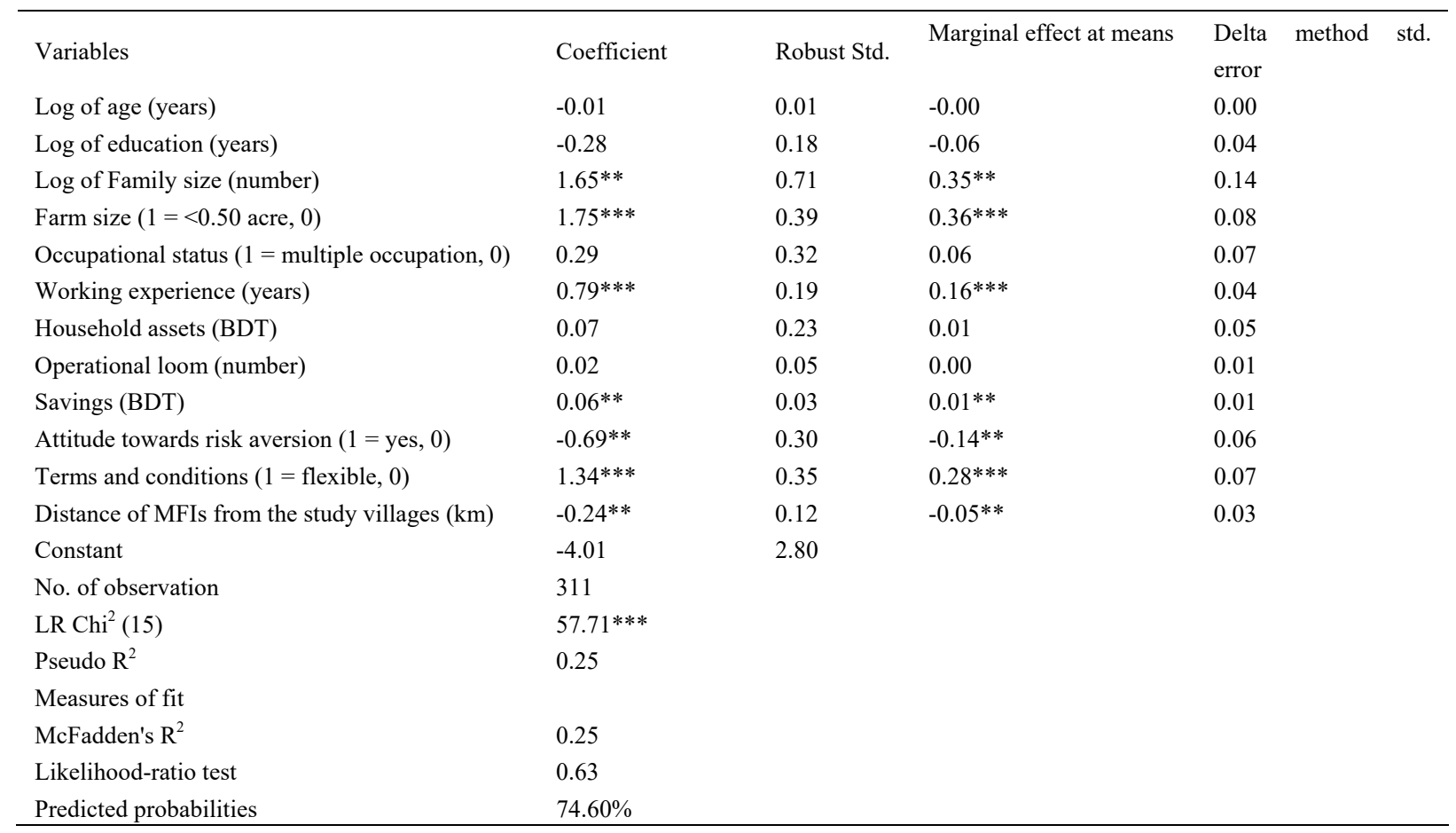

Note. $* * *$ Significant at $1 \%, * *$ Significant at $5 \%, *$ Significant at $10 \%$.

Source. Field data, 2015

\subsection{Post-Estimation Results}

Some post-estimation tests were conducted to determine the best fit of the estimated model. These results are also presented in Table 2 . 
The first test is called the test of goodness of fit. This text examines the closeness of the estimated model to the observed data (Spermann, 2009). Here, the estimated value of 0.25 implies that the analyzed model demonstrates about $25 \%$ variations in the outcome variable with the help of the given values of the explanatory variables.

The second test was the likelihood ratio test. It refers to testing the sensitivity of the restrictive model with a less restrictive one. A significant test value implies that the estimated model is weakly fitted. This test provided a Chi-squared value of 0.63 which failed to have 5\% significance level. Therefore, the null hypothesis of the study is accepted and can be said that the predictors used in the current study make significant difference in predicting the dependent than the model with additional variable.

Finally, the predicted probabilities of the dependents variable for each observation being 1 were also computed. As the estimated probability of 0.75 is greater than 0.5 , it can be concluded that the model correctly specifies $75 \%$ likeliness of the dependent variable being 1 in this study.

\subsection{Summary and Policy Recommendations}

The finding suggests that the family size and the land holdings of the respondents, their work experience, savings level and the flexibility in the terms and conditions of loan use and repayment play a prominent role in determining the handloom weavers' credit access. However, some variables such as the risk aversion attitude of the respondents and the distance between the MFIs from the study villages reduce such probability. Therefore, this study mainly recommends that the credit institutions should introduce favorable terms and conditions for the clients. At the same time, respondents should make use of their skills and capabilities acquired over the years in rational decision making which should be jointly carried out by the family members, particularly the active adults. Only then they would be able to earn sufficient income as well as save enough to continue the business. From the lender's side, they should ensure the least possible distance to be traveled by the respondents to ensure their smooth accessibility. It can be done by opening up more branches at the villages. Following those recommendations might help to improve the credit access of the small-scale entrepreneurs in Bangladesh. In the long run, the users may not need credit at all due to their good economic condition initially advanced by the access to the credit facilities. Finally, it is concluded that credit will help to expand the business scale of the handloom weavers only if it is delivered to the eligible and needy clients. Otherwise, it will just contribute to the misuse of the funds for unproductive purposes which will make the organization financially unsustainable.

\section{Conclusion}

In Bangladesh, the lack of credit access is regarded as one of the major obstacles of structural transition from the traditional manual-based to modern technology based production system. In this regard, facilitating the access to the credit may help these producers group sustaining their livelihood in the rural setup. However, the majority of the small-scale entrepreneurs who are also regarded as the dominant non-agricultural households are denied from adequate credit facilities. Even those who are already the accessed borrowers, the study on which factors determines their credit accessibility is missing from the vast number of microfinance literature. In order to fill this knowledge gap, this study has investigated the factors that determine the credit accessibility by the handloom weavers in Bangladesh. From the policy perspective, such an analysis is important for increasing the credit access by the studied group who is competing with other participants in the existing financial markets and who need it most. From the institutional perspective, it is important for allocating the organization's scarce resources to the eligible clients to achieve the two critical goals (i.e., outreach and financial sustainability) of the MFIs. Through the identification of various socioeconomic and institutional factors under the highlighted context, this study intends to contribute to the existing literature of the similar kinds.

\section{Acknowledgement}

This study has been generated using the data collected for a doctoral study conducted at the University of Hohenheim, Germany and was funded by German Academic Exchange Service (grant number 91538050) through the scholarship program "Agricultural Economics, Bioeconomy, and Rural Development". The authors also want to thank the respondents for their kind cooperation during the data collection.

\section{References}

Anang, B. T., Sipiläinen, T., Bäckman, S., \& Kola, J. (2015). Factors influencing smallholder farmers' access to agricultural microcredit in Northern Ghana. African Journal of Agricultural Research, 10(24), 2460-2469. https://doi.org/10.5897/AJAR2015.9536

Banarjee, S., Muzib, M. M., \& Sharmin, S. (2014). Status of handloom workers and causes of their migration : A study in H/handloom industry of Tangail district, Bangladesh. Research on Humanities and Social Sciences, $4(22), 157-162$. 
Bangladesh Bureau of Statistics (BBS). (2003). Report on Bangladesh Handloom Census. Planning Division, Ministry of Planning, Government of the Peoples' Republic of Bangladesh, Dhaka.

Chauke, P. K., Motlhatlhana, M. L., Pfumayaramba, T. K., \& Anim, F. D. K. (2013). Factors influencing access to credit: A case study of smallholder farmers in the Capricorn district of South Africa. African Journal of Agricultural Research, 8(7), 582-585. https://doi.org/10.5897/AJAR2013.6700

Diagne, A., \& Zeller, M. (2001). Access to credit and its impact on welfare in Malawi. (Research Report 116). International Food Policy Research Institute. Washington DC. https://doi.org/116

Dzadze, P., Osei Mensah, J., Aidoo, R., \& Nurah, G. K. (2012). Factors determining access to formal credit in Ghana: A case study of smallholder farmers in the Abura- Asebu Kwamankese district of central region of Ghana. Journal of Development and Agricultural Economics, 4(14), 416-423. https://doi.org/10.5897/JDAE12.099

Gelos, R. G., \& Werner, A. M. (2002). Financial liberalization, credit constraints and collateral: investment in the Mexican manufacturing sector. Journal of Development Economics, 67(1), 1-27. https://doi.org/10.1016/S0304-3878(01)00175-4

Gujarati, D. N., \& Porter, D. C. (2008). Basic Econometrics (5th ed.). New York, NY: McGraw-Hill/Irwin.

Hertz, T. (2009). The Effect of nonfarm income on investment in Bulgarian family farming. Agricultural Economics, 40(2), 161-176. https://doi.org/10.1111/j.1574-0862.2009.00367.x

Islam, M. K., \& Hossain, M. E. (2012). An Analysis of present scenario of handloom weaving industry in Bangladesh. Rabindra Journal, 03(1), 1-14. https://doi.org/10.13140/RG.2.1.3129.5205.

Karanja, J. G., Mwangi, A. K., \& Nyakarimi, S. N. (2014). Analysis of factors influencing access to credit services by women entrepreneurs in Kenya. Research Journal of Finance and Accounting, 5(11), 34-42.

Kohansal, M. R., Ghorbani, M., \& Mansoori, H. (2008). Effect of credit accessibility of farmers on agricultural investment and investigation of policy options in Khorasan Razavi Province. Journal of Applied science, $8(23), 4455-4459$.

Liton, M. R. I., Islam, T., \& Saha, S. (2016). Present scenario and future challenges in handloom industry in Bangladesh. Social Sciences, 5(5), 70-76. https://doi.org/10.11648/j.ss.20160505.12

Love, I., \& Sánchez, S. M. (2009). Credit constraints and investment behavior in Mexico's rural economy (Policy Research Working Paper 5014). The World Bank. Retrieved from https://core.ac.uk/download/pdf/6319582.pdf

Luan, D. D. (2015). Access to credit and household income in the northern mountains of Vietnam (Doctoral Dissertation), 156, Justus-Liebig University of Giessen, Germany.

McNamara, K. T., \& Weiss, C. (2005). Farm household income and on and off-farm diversification. Journal of Agricultural and Applied Economics, 37(1), 37-48.

Motsoari, C., Cloete, P. C., \& van Schalkwyk, H. D. (2015). An analysis of factors affecting access to credit in Lesotho's smallholder agricultural sector. Development Southern Africa, 32(5), 592-602, https://doi.org/10.1080/0376835X.2015.1044077

Parvin, M. T., \& Haque, S. (2017). An analysis of socioeconomic indicators of rural non-agricultural households in Bangladesh: a case of handloom weaving. Journal of Economics and Sustainable Development, 8(12), 1-12.

Pitt, M. M. (2000). The effect of non-agricultural self-employment credit on contractual relations and employment in agriculture: the case of microcredit programmes in Bangladesh. The Bangladesh Development Studies, 26(2\&3), 15-48. https://doi.org/10.2307/40795611

Rahman, A., Mukul, A. Z. A., \& Anny, S. A. (2014). A study on powerloom business in some selected areas of Sirajganj district: it focuses on present scenario and future prospect. International Journal of Business and Economics Research, 3(4), 140-149. https://doi.org/10.11648/j.ijber.20140304.11

Rahman, M. M. (2013). Prospects of handloom industries in Pabna, Bangladesh. Global Journal of Management and Business Research Interdisciplinary, 13(5), 9-17.

Rahman, M. W., Luo, J., Ahmed, S., \& Xiaolin, W. (2012). The synthesis of Grameen Bank, BRAC and ASA microfinance approaches in Bangladesh. World Applied Sciences Journal, 20(7), 1055-1062. https://doi.org/10.11648/j.ijber.20140304.1110.5829/idosi.wasj.2012.20.07.1558.

Reardon, T., Crawford, E., \& Kelly, V. (1994). Links between nonfarm income and farm investment in african 
households: adding the capital market perspective. American Journal of Agricultural Economics, 76(5), 1172-1176.

Sharma, M., \& Zeller, M. (1997). Repayment performance in group-based credit programs in Bangladesh: An empirical analysis. World Development, 25(10), 1731-1742. https://doi.org/10.1016/S0305-750X(97)00063-6

Siwale, J. N., \& Ritchie, J. (2011). Disclosing the loan officer's role in microfinance development. International Small Business Journal, 30(4), 432-450. https://doi.org/10.1177/0266242610373687

Spermann, A. (2009). The Probit Model. University of Freiburg, Retrieved from https://goo.gl/KqLmaE

Torres-Reyna O. (2014). Predicted probabilities and marginal effects after (ordered) logit/probit using margins in Stata. 1-38. Princeton University. Retrieved from http://www.princeton.edu/ otorres/Margins.pdf

Williams, R. (2016). Marginal effects for continuous variables. University of Notre Dame. Retrieved from http://www3.nd.edu/ rwilliam/

\section{Notes}

Note 1. Handloom weaving is referred as the process of producing the woven fabric (i.e. cloth) through the manual exercise of someone's hand and foot. The process requires a machine called loom which is made of wood and iron and is operated without any mechanical power or electricity. Handloom weavers are those whose livelihood is dependent on the handloom weaving occupation. For further reading: BBS (2003), Islam and Hossain (2012)

Note 2. The Logit model is not a unique analytical method. Therefore, the detailed specification is not provided in this study. For detailed understanding and its econometric specification, please read: Gujarati \& Porter (2008)

Note 3. 1 US Dollar = approximately 78 BDT during December 2015

Note 4 . The handloom that is usable for the production purpose throughout the year is termed as the operational handloom/machine/loom/device.

\section{Copyrights}

Copyright for this article is retained by the author(s), with first publication rights granted to the journal.

This is an open-access article distributed under the terms and conditions of the Creative Commons Attribution license (http://creativecommons.org/licenses/by/4.0/). 